\title{
Removable partial or complete dentures exposed to beverages and mouthwashes: evaluation of microhardness and roughness
}

\author{
Próteses parciais e totais removíveis expostas a bebidas e enxaguatórios bucais: \\ avaliação da microdureza e rugosidade
}

Fernanda Alves FEITOSA a^, Mateus Guimarães Lage REGGIANIª, Rodrigo Máximo de ARAÚJOa

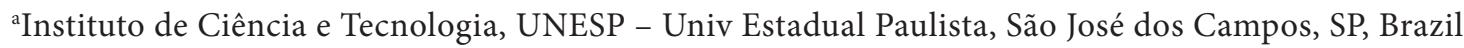

\begin{abstract}
Resumo
Objetivo: Avaliar a rugosidade e microdureza de uma resina acrílica utilizada para base de prótese quando submetidas a diferentes bebidas e enxaguatórios bucais. Material e método: Oitenta amostras retangulares foram confeccionadas com polimetilmetacrilato, e separados em 8 grupos. As amostras foram avaliadas quanto àmicrodureza e rugosidade (Knoop) superficiais e imersas por 10 minutos em um dos seguintes produtos: café, suco artificial de limão, gluconato de clorexidina, vinho tinto, refrigerante a base de cola, vinagre e antissépticos com e sem álcool. Após a imersão nas soluções, as amostras foram acondicionados em saliva artificial por 23 horas e 50 minutos, completando o período de 24 horas. Esse procedimento ocorreu por 14 dias consecutivos e após esse período outras mensurações de microdureza e rugosidade foram realizadas. Os dados obtidos foram analisados estatisticamente pela ANOVA não paramétrico, KruskalWalis e teste de Dunn para a microdureza e ANOVA e $t$-student ( $\alpha=5 \%$ ) para rugosidade. Resultado: Para microdureza foram encontradas diferenças significativas entre os grupos onde houve imersão em clorexidina, antisséptico sem álcool e refrigerante de coca-cola. Para a rugosidade foi observado que a media entre os valores antes e após a imersão nos produtos diferiu estatisticamente em todos os grupos, porém sem diferença entre eles. Conclusão: A microdureza do polimetilmetacrilato foi afetada pela exposição ao gluconato de clorexidina, antisseptico sem álcool e refrigerante à base de coca-cola. A rugosidade da superfície do polimetilmetacrilato foi afetada por todos os produtos estudados.
\end{abstract}

Descritores: Prótese dentária; base de prótese; resina acrílica; enxaguantes bucais.

\begin{abstract}
Purpose: To evaluate microhardness and roughness of denture base polymethylmethacrylate resinn exposed to acid beverages and mouthwashes. Material and method: Rectangular samples $(n=80)$ were prepared from poly (methyl methacrylate) (PMMA). They were divided into 8 groups and had the initial microhardness and Knoop roughness measured. Samples of each group were immersed for 10 min into a test solution (coffee, lemon juice, chlorhexidine gluconate, red wine, cola-based soft drink, vinegar or antiseptic with and without alcohol) and after stored in artificial saliva for $23 \mathrm{~h}$ and $50 \mathrm{~min}$, completing a period of $24 \mathrm{~h}$. This procedure was performed for 14 consecutive days and after this period the microhardness and surface roughness measurements were made again. Data were statistically analyzed using ANOVA non parametric, Kruskal-Walis and the Dunn's test for microhardness and the t-Student and ANOVA for roughness. Result: For microhardness there were found statistically significant differences among the chlorhexidine gluconate solution, antiseptic without alcohol and cola-based soft drink. For roughness was observed that the mean values between the initial period and after immersion in the test products differed statistically in all groups, without difference among groups. Conclusion: The microhardness of poly(methyl methacrylate) was affected by continue exposition to chlorhexidine gluconate, antiseptic without alcohol and cola-based soft drink. The roughness of poly(methyl methacrylate) is negatively influenced by the exposure to all tested products. It may be concluded that both, microhardness and roughness, were affected by the treatments.
\end{abstract}

Descriptors: Dental prosthesis; denture bases; acrylic resin; mouthwashes.

\section{INTRODUCTION}

Aging of population has reached an increasing speed in developing countries. Older people are among the most affected by oral and systemic diseases, with clear impacts on their quality of life. The consequences of accumulation of oral diseases are reflected in severe teeth loss and use of prosthesis don't always in proper conditions. As a result, esthetic, function, nutrition and self-esteem may be harmed ${ }^{1,2}$.

Removable partial and complete dentures are good options for patients requiring rehabilitation after the loss of some or all of their 
teeth. These dentures are fabricated withacrylic resin, a low cost polymer material based on poly (methyl methacrylate) (PMMA), which is relatively easy to manipulate ${ }^{3}$. The acrylic resin may be classified according to its mode of activation, as chemically-polymerizated (cold-polymerized resins), heat-polymerizated (polymerized using water bath or microwave oven) and light-polymerizated types ${ }^{4}$.

Bettencourt et al. ${ }^{5}$ studied acrylic resins and observed that multiple factors are responsible for their biodegradation, such as the characteristics of saliva, thermal and chemical variations, diet, use of cleansing products, toxic potential of material components and changes in physical and mechanical properties.

The effect in roughness, hardness and color stability of acrylic resin bases when cleaning with different mouthwashes has been studied $^{6-9}$. Mouthwashes are commonly recommended to prevent biofilm formation and microorganisms colonization ${ }^{3}$. Some studies have reported the influence of immersion in chemical and alcoholbased disinfectants in the physical and flexural strength of acrylic $\operatorname{resin}^{10-12}$. These researches may propel the need to investigate these correlations with the denture acrylic resin.

Machado et al. ${ }^{11}$ showed that when reline resins and denture base resins are immersed in sodium perborate, an alkaline material, their roughness is significantly increased, however, their hardness is not harmed when they are exposed to different disinfection cycles in microwave ovens and in $3.8 \%$ sodium perborate. Whereas Neppelenbroek et al. ${ }^{13}$ studying chemical disinfection in water, $3.78 \%$ sodium perborate; $4 \%$ chlorhexidine gluconate and $1 \%$ sodium hypochlorite found that the products negatively affected the hardness of two different acrylic resins used for denture bases, however, this effect was reverted after 15 days storage in water, suggesting to the clinician that dentures should be immersed in water after the disinfection cycle, to minimize the harmful effects of the procedure. It may occurs because water molecules act as a plasticizer and the flow of long-chain polymers can be facilitated. This process is a result of reduce of concentration of residual monomers.

Effects of exposure of acrylic resins and relining materials to the oral medium and to foods and beverages consumed by the patient have not yet been extensively studied, in spite of great importance to clinical practice ${ }^{3,10,14}$. The alteration in dimensional stability of denture base resins may indicate aging or damage to the material, which may occur due to the ingestion of acid beverages $(\mathrm{pH}<5)$, which in contact with stock artificial teeth or acrylic resin, denture bases may compromise their properties, in addition to favoring bacterial biofilm adhesion to their surfaces ${ }^{10}$.

The aim of this study was to evaluate the effect of acid beverages and mouthwashes on the microhardness and roughness of denture base acrylic resin. The tested hypothesis would be that the low $\mathrm{pH}$ and use of alcohol-based mouthwashes may adversely affect the roughness and hardness of denture acrylic resin.

\section{MATERIAL AND METHOD}

Pink acrylic resin (Jet, Clássico, Sao Paulo, SP, Brazil) were manipulated in proportion 3:1 (powder/liquid) and immediately included into silicone molds until polymerization $(\mathrm{n}=80)$, resulting in rectangular samples with dimensions of $2.5 \times 5.0 \times 1.0 \mathrm{~cm}$. The samples were embedded in transparent acrylic resin (Jet), using a cylinder-shaped silicone matrix, to facilitate the polishing procedures and microhardness and roughness measurements.

The samples were polished (Pantec Polipan 2, Panambra, Sao Paulo, SP, Bazil) with a sequence of water abrasive papers (\#600, $\# 800$, \#1.200 and a felt disc). After this, the samples were randomly divided into eight experimental groups:

GCof: Instant coffee (Nescafe, Nestle, Araras, SP, Brazil) prepared according to manufacturer's instruction.

GJui: Light artificial juice powder, lemon flavored (Clight, Mondelez , SP, Brazil) - prepared according to manufacturer's instruction;

GChl: $0.12 \%$ Chlorhexidine gluconate (PerioGard, ColgatePalmolive, Sao Paulo, SP, Brazil);

GWine: Red table wine (San Tomé, Alberto Belesso, Itupeva, SP, Brazil);

GCola: Cola-based soft drink (Coca-Cola; FEMSA, Jacarei, SP, Brazil);

GVin: White wine vinegar (Castelo, Castelo Foods, Jundiai, SP, Brazil);

GAnt: Oral antiseptic with fluoride, mint flavored, without alcohol (Colgate Plax Soft Milk, Colgate-Palmolive, SP, Sao Paulo, Brazil);

GAntAlc: Oral antiseptic mint flavored, with alcohol (Listerine, Johnson \& Johnson, Sao Paulo, SP, Brazil).

Before the test samples immersion in the solutions the initial Knoop microhardness and roughness measurements were made. After, the test samples of each group were immersed in the respective products for $10 \mathrm{~min}$ and stored in artificial saliva for $23 \mathrm{~h}$ and $50 \mathrm{~min}$, completing a period of $24 \mathrm{~h}$. This procedure was performed for 14 consecutive days, and after this period the final microhardness and surface roughness measurements were made.

A microdurometer (FM 700, FutureTech corp., Tokyo, Japan) was used fitted with an indenter using a 100gf and dwell time of $10 \mathrm{sec}$, coupled to a microcomputer and a specific software program to analyze the images (Cams - Win - New Age Industries,USA). All the samples were demarcated, dividing them into quadrants, for determination and standardization of the readout locations.

During the test, the microdurometer activated a pyramid-shaped diamond penetrator tip under a vertical static load of $100 \mathrm{gf} / 10 \mathrm{sec}$ and the readout was made with an objective at 10X magnification. When activated, the penetrator performed a compression on the sample surface, generating a diamond-shaped geometric form. The microdurometer made the calculations automatically.

Quantitative surface roughness analysis ( $\mathrm{Ra}$ and $\mathrm{Rz}$ ) was performed with the analyzer tip in a Mitutoyo SJ 400 rugosimeter (Mitutoyo, Tokyo, Japan) by a single trained examiner, using the following parameters: $\mathrm{Ra}$ (mean roughness) - corresponding to the arithmetic mean of the absolute values of roughness profile ordinates (peaks and valleys) in relation to the midline, within the measurement run; and $\mathrm{Rz}$ (mean roughness depth) corresponding to the arithmetic mean of the absolute values of roughness profile ordinates in relation to the most distant points above and below the midline. Three perpendicular measurements were taken on the sample 
surfaces with a distance of $2 \mathrm{~mm}$ between each measurement. For each sample, a mean value was obtained from three measurements, and afterwards the average was obtained for each group.

The results of microhardness were analyzed with KruskalWallis non parametric ANOVA and Dun Test, and the results of roughness was submitted to one-way ANOVA and Student- $t$ test for paired samples $(\mathrm{p}<0.05)$.

\section{RESULT}

\section{Microhardness}

To evaluate the microhardness results the Kruskal-Wallis non parametric ANOVA test was used. The analysis showed statistically significant differences on the microhardness values $(\mathrm{P}=0.0017$ $<0.05$ ). The cola-based soft drink group (Group GCola) showed the lower alteration on the microhardness surface (Table 1).

Statistically significant different was found between the experimental groups, and after this Dunn's test was applied to locate where the difference occurred (Table 2).

In Dunn's test difference was observed between the Groups chlorhexidine and antiseptic without alcohol, and the Group colabased soft drink, with the other groups presenting intermediate values. Greater alteration in microhardness when chlorhexidine and the antiseptic without alcohol were used.

\section{Roughness}

Table 3 shows the comparison of the roughness condition in the immediate period and after solution immersion and the interval of confidence (IC: 95\%) in the comparison on the mean roughness values $(\mathrm{Ra})$ of beverages for all experimental groups, resulting from the Student's- $t$ test for paired samples ( $d f=9), \alpha=5 \%$. There were significative differences between the periods (imediate and after immersion) for all groups, but there was no significative differences between the groups in both periods.
Table 4 shows the comparison of the roughness condition in the immediate period and after immersion, according to the type of test product. Interval of Confidence (IC: 95\%) in the comparison on the mean roughness values $(\mathrm{Rz})$ of beverages for all experimental groups, resulting from the Student's- $t$ test for paired samples $(\mathrm{df}=9), \alpha=5 \%$.

In the period after immersion there was an increase in roughness in comparison with the initial period (Tables 3 and 4). The mean values of the periods differed statistically both for $\mathrm{Ra}$ and $\mathrm{Rz}$, in each of the groups.

For comparison among the groups with respect to the initial difference and after immersion in the test products the one-way ANOVA was applied (Table 5), and the results for the Ra values and for the $\mathrm{Rz}$ values showed no difference between the values or between the groups.

\section{DISCUSSION}

In this in vitro study it was observed that $0.12 \%$ chlorhexidine gluconate and mint flavored oral antiseptic without alcohol showed the greatest differences between initial microhardness and after solution submersion for 14 days, characterizing a harmful effect and a decrease on microhardness values. Asad et al. ${ }^{12}$ used $2 \%$ glutaraldehyde, $0.5 \%$, chlorhexidine and a disinfectant solution with alcohol on acrylic resin for $24 \mathrm{~h}$, showing no significant change in the values; however, significant alteration was observed after immersion for 7 days,. According to authors, the alteration may have occurred due to the absorption of chemical products by the acrylic resin, resulting in a structural change of the polymer. In addition, the water re-immersion increased the microhardness, suggesting a structural reorganization in the polymer changed by the solution immersion.

In this study it was observed that all solutions promoted alteration in the acrylic resin microhardness; However, statistically significant values were only found between the Groups $0.12 \%$ chlorhexidine and the disinfectant solution without alcohol in comparison with the cola-based soft drink group (Table 2), whereas the other groups

Table 1. Mean, standard deviation and median of the microhardness values of the denture base acrylic resin - ANOVA

\begin{tabular}{cccccccccc}
\hline \multicolumn{7}{c}{ Difference - before and after immersion } & & & \\
\hline Variable & Group & N & Mean & S.D. & Minimum & Q1 & Median & Q3 \\
\hline 60.28 & GCof & 10 & 18.96 & 16.23 & -3.49 & 12.28 & 16.75 & 21.25 \\
33.85 & GJui & 10 & 12.13 & 9.05 & 2.20 & 6.84 & 9.19 & 15.88 \\
66.97 & GChl & 10 & 35.47 & 23.23 & 6.46 & 11.82 & 36.56 & 57.67 \\
48.11 & GWine & 10 & 14.63 & 14.00 & 2.36 & 4.14 & 12.04 & 20.12 \\
12.02 & GCola & 10 & 3.87 & 4.78 & -3.48 & 1.35 & 2.93 & 6.17 \\
39.90 & GVin & 10 & 14.80 & 14.03 & -4.34 & 2.35 & 16.45 & 25.58 \\
55.63 & GAnt & 10 & 25.78 & 17.77 & -0.43 & 12.46 & 24.93 & 39.74 \\
31.76 & GAntAlc & 10 & 13.63 & 6.59 & 9.03 & 9.95 & 12.03 & 13.90 \\
\hline
\end{tabular}

Kruskal-Wallis non parametric ANOVA, P- $0.0017<0.05$. 
had intermediate values. There was greater change in microhardness when using the chlorhexidine and antiseptic without alcohol.

Similary to Asad et al. ${ }^{12}$, absorption of the solutions by the acrylic resin may have occurred in this study, resulting in different levels of softening by the different solutions. In addition, the exposure time of $10 \mathrm{~min}$ in the solutions and the storage in artificial saliva for $23 \mathrm{~h}$ and $50 \mathrm{~min}$, completing a period of $24 \mathrm{~h}$ for 14 days is a factor influencing the results. The exposure time recommended

Table 2. Difference in microhardness among Groups - Dunn's test (5\%)

\begin{tabular}{ccll}
\hline Group & Mean & \multicolumn{2}{c}{ Homogeneous } \\
\hline C & $\mathbf{5 9 . 0 0 0}$ & A & \\
G & 53.500 & A & B \\
A & 47.900 & A & B \\
F & 38.700 & A & B \\
H & 38.700 & A & B \\
D & 37.000 & A & B \\
B & 33.400 & A & B \\
\hline E & 15.800 & & \\
\hline
\end{tabular}

by the manufacturers is from 10 to $30 \mathrm{~min}$, which was extended to 14 days simulating a continuous period of use ${ }^{12}$.

Acrylic resin denture bases may also undergo alterations in hardness and roughness as a result of the action of foods and beverages, disinfectants, saliva, surface texture and porosities resulting from the laboratory procedure, in addition to the time of use ${ }^{15}$.

During acrylic resin polymerization, the residual monomer may act as resin plasticizer, changing the properties of the acrylic resin. Storage in water or artificial saliva is another factor triggering alterations, and could interfere in the properties of denture base materials, due to the absorption of water with consequent alteration in the material ${ }^{8,14}$. When the surface microhardness was evaluated in this study, it was verified that chlorhexidine and disinfectant without alcohol produced the greatest alterations in the acrylic resin. Similar behavior was observed for roughness.

When acrylic resin roughness was evaluated in the different groups there was difference between the initial period and immersion in the solution for $10 \mathrm{~min} / 14$ days. This difference remained constant among the groups and no statistically significance difference was found among them. Azevedo et al. ${ }^{8}$, submitted the samples for 7 days in disinfectants solutions, and Ural et al. ${ }^{14}$, immersed samples for a week (5 hours/day). Both studies shown small or no significant changes in roughness between the periods of evaluation when test

Table 3. Comparison of the mean roughness (Ra), resulting from the Student's- $t$ test for paired samples ( $d f=9), \alpha=5 \%$

\begin{tabular}{llll}
\hline \multicolumn{1}{c}{ Groups } & Immediate & After & IC $(\mathbf{9 5 \% )} ; \mathbf{p}$-value \\
\hline A:Coffee & $0.054 \pm 0.008$ & $0.102 \pm 0.011$ & 0.037 to $0.058 ; \mathrm{p}=0.001^{*}$ \\
B: Juice & $0.051 \pm 0.015$ & $0.104 \pm 0.017$ & 0.036 to $0.069 ; \mathrm{p}=0.001^{*}$ \\
\hline C: Chlorhexidine & $0.054 \pm 0.011$ & $0.126 \pm 0.036$ & 0.051 to $0.092 ; \mathrm{p}=0.001^{*}$ \\
D: Red Wine & $0.043 \pm 0.001$ & $0.120 \pm 0.019$ & 0.063 to $0.089 ; \mathrm{p}=0.001^{*}$ \\
E: Soft Drink & $0.044 \pm 0.011$ & $0.093 \pm 0.016$ & 0.038 to $0.058 ; \mathrm{p}=0.001^{*}$ \\
F: Vinegar & $0.058 \pm 0.021$ & $0.102 \pm 0.038$ & 0.012 to $0.075 ; \mathrm{p}=0.012^{*}$ \\
\hline G: antisept+fluoride without alcohol & $0.072 \pm 0.027$ & $0.111 \pm 0.037$ & 0.016 to $0.063 ; \mathrm{p}=0.004^{*}$ \\
\hline H: antisept+fluoride with alcohol & $0.063 \pm 0.034$ & $0.121 \pm 0.066$ & 0.025 to $0.090 ; \mathrm{p}=0.003^{*}$ \\
\hline
\end{tabular}
${ }^{*} \mathrm{p}<0.05$.

Table 4. Comparison of the mean roughness condition $(\mathbf{R z})$ in the immediate period and after immersion in the test products for all the experimental groups, resulting from the Student's- $t$ test for paired samples

\begin{tabular}{llll}
\multicolumn{1}{c}{ Groups } & Immediate & After & IC (95\%); -value \\
\hline A:coffee & $0.464 \pm 0.168$ & $0.939 \pm 0.126$ & 0.317 to $0.632 ; \mathrm{p}=0.001^{*}$ \\
B:Juice & $0.392 \pm 0.134$ & $0.889 \pm 0.177$ & 0.318 to $0.676 ; \mathrm{p}=0.001^{*}$ \\
C: Chlorhexidine & $0.424 \pm 0.212$ & $0.942 \pm 0.275$ & 0.373 to $0.662 ; \mathrm{p}=0.001^{*}$ \\
D: Red Wine & $0.354 \pm 0.138$ & $0.903 \pm 0.125$ & 0.477 to $0.620 ; \mathrm{p}=0.001^{*}$ \\
E: Soft Drink & $0.344 \pm 0.079$ & $0.727 \pm 0.146$ & 0.291 to $0.475 ; \mathrm{p}=0.001^{*}$ \\
F: Vinegar & $0.454 \pm 0.202$ & $0.850 \pm 0.242$ & 0.176 to $0.615 ; \mathrm{p}=0.003^{*}$ \\
G:antisept+fluoride without alcohol & $0.493 \pm 0.098$ & $0.900 \pm 0.165$ & 0.291 to $0.522 ; \mathrm{p}=0.001^{*}$ \\
\hline \multicolumn{1}{c}{ H:antisept+fluoride with alcohol } & $0.460 \pm 0.236$ & $0.963 \pm 0.313$ & 0.278 to $0.727 ; \mathrm{p}=0.001^{*}$ \\
\hline
\end{tabular}


Table 5. Descriptive statistics for Ra corresponding to difference in the values of the groups

\begin{tabular}{|c|c|c|c|c|c|c|c|c|}
\hline Variable & Group & $\mathbf{N}$ & Mean & SD & CoefVar & Minimum & Median & Maximum \\
\hline \multirow[t]{8}{*}{ Ra-diffa } & A & 10 & 0.0480 & 0.0148 & 31.01 & 0.0200 & 0.0500 & 0.07 \\
\hline & B & 10 & 0.0531 & 0.0227 & 42.86 & 0.0200 & 0.0535 & 0.09 \\
\hline & $\mathrm{C}$ & 10 & 0.0716 & 0.0282 & 39.39 & 0.0400 & 0.0650 & 0.14 \\
\hline & $\mathrm{D}$ & 10 & 0.0766 & 0.0179 & 23.39 & 0.0600 & 0.0720 & 0.12 \\
\hline & E & 10 & 0.0483 & 0.0137 & 28.51 & 0.0230 & 0.0470 & 0.07 \\
\hline & F & 10 & 0.0435 & 0.0441 & 101.30 & -0.0230 & 0.0435 & 0.12 \\
\hline & G & 10 & 0.0398 & 0.0334 & 83.86 & -0.0040 & 0.0335 & 0.09 \\
\hline & $\mathrm{H}$ & 10 & 0.0576 & 0.0458 & 79.58 & 0.0130 & 0.0520 & 0.16 \\
\hline \multicolumn{9}{|c|}{$\left(\right.$ ANOVA, statistic $\mathrm{F}_{\mathrm{d}(7 ; 72)}=1.92 ; \mathrm{p}$-value $\left.=0.079>0.05\right)$} \\
\hline \multirow[t]{8}{*}{ Rz-diffa } & A & 10 & 0.4750 & 0.2200 & 46.31 & -0.0300 & 0.5850 & 0.67 \\
\hline & B & 10 & 0.4970 & 0.2501 & 50.32 & 0.2300 & 0.4050 & 0.94 \\
\hline & $\mathrm{C}$ & 10 & 0.5177 & 0.2019 & 38.99 & 0.3000 & 0.4850 & 0.81 \\
\hline & $\mathrm{D}$ & 10 & 0.5490 & 0.1002 & 18.24 & 0.4000 & 0.5150 & 0.73 \\
\hline & E & 10 & 0.3830 & 0.1287 & 33.60 & 0.2000 & 0.3650 & 0.60 \\
\hline & F & 10 & 0.3960 & 0.3069 & 77.51 & -0.0300 & 0.3300 & 0.96 \\
\hline & G & 10 & 0.4070 & 0.1615 & 39.67 & 0.2000 & 0.4150 & 0.66 \\
\hline & $\mathrm{H}$ & 10 & 0.5030 & 0.3137 & 62.36 & -0.0700 & 0.5000 & 0.94 \\
\hline
\end{tabular}

$\left(\right.$ ANOVA, statistic $\mathrm{F}_{\mathrm{df}(7 ; 72)}=0.78 ; \mathrm{p}$-value $\left.=0.606>0.05\right)$.

the effects of disinfectants in denture base resin and relining resins. The differences among the findings may occur due to solutions types, different brands of denture base materials, exposure times and equipment used for evaluation.

Jin et al. ${ }^{16}$ evaluating denture relining materials (soft denture lining) observed differences between the commercial brands, with severe changes in roughness. Its known that cleanser products like toothbrushes and toothpastes cause denture base surface abrasion, but there are no sufficient researches about the influence of mouthwashes on its surface ${ }^{16}$. Regis et al. ${ }^{17}$ verified the effects of different alcohol concentrations in roughness and microhardness of denture base materials. They found alteration in these properties, differing from the findings of the current study, in which it was verified that the results for disinfectant with alcohol and red wine did not differ statistically from the other groups, and that chlorhexidine and disinfectant without alcohol were the solutions most harmful for microhardness.

Considering that the roughness of dentures facilitates bacterial activity and may cause traumas to the soft tissues ${ }^{18}$, leading to stomatitis or other types of lesions and contributing to tissue injuries, the maintenance of surface smoothness is important for the good hygiene of denture bases and oral health.

\section{CONCLUSION}

- The greatest difference in microhardness occurred in the groups of chlorhexidine and antiseptic without alcohol, and the lowest difference in the cola-based soft drink;

- There was an increase in roughness between the initial period and after submersion of test specimens in the test products; and

- There was no difference in roughness among the groups.

\section{REFERENCES}

1. Tsakos G, Watt RG, Rouxel PL, de Oliveira C, Demakakos P. Tooth loss associated with physical and cognitive decline in older adults. J Am Geriatr Soc. 2015 Jan;63(1):91-9. http://dx.doi.org/10.1111/jgs.13190. PMid:25523131

2. McKenzie-Green B, Giddings LS, Buttle L, Tahana K. Older peoples' perceptions of oral health: 'it's just not that simple'. Int J Dent Hyg. 2009 Feb;7(1):31-8. http://dx.doi.org/10.1111/j.1601-5037.2008.00328.x. PMid:19215309

3. Hong G, Murata H, Li Y, Sadamori S, Hamada T. Influence of denture cleansers on the color stability of three types of denture base acrylic resin. J Prosthet Dent. 2009 Mar;101(3):205-13. http://dx.doi.org/10.1016/S0022-3913(09)60032-9. PMid:19231574 
4. Sepúlveda-Navarro WF, Arana-Correa BE, Borges CP, Jorge JH, Urban VM, Campanha NH. Color stability of resins and nylon as denture base material in beverages. J Prosthodont. 2011 Dec;20(8):632-8. http://dx.doi.org/10.1111/j.1532-849X.2011.00791.x. PMid:22040527

5. Bettencourt AF, Neves CB, Almeida MS, Pinheiro LM, Oliveira SA, Lopes LP, et al. Biodegradation of acrylic based resins: a review. Dent Mater. 2010 May;26(5):e171-80. http://dx.doi.org/10.1016/j.dental.2010.01.006. PMid:20189238

6. Hersek N, Canay S, Uzun G, Yildiz F. Color stability of denture base acrylic resins in three food colorants. J Prosthet Dent. 1999 Apr;81(4):3759. http://dx.doi.org/10.1016/S0022-3913(99)80001-8. PMid:10095204

7. Rodrigues Garcia RC, Joane Augusto S Jr, Rached RN, Del Bel Cury AA. Effect of denture cleansers on the surface roughness and hardness of a microwave-cured acrylic resin and dental alloys. J Prosthodont. 2004 Sept;13(3):173-8. http://dx.doi.org/10.1111/j.1532-849X.2004.04028.x. PMid:15345017

8. Azevedo A, Machado AL, Vergani CE, Giampaolo ET, Pavarina AC, Magnani R. Effect of disinfectants on the hardness and roughness of reline acrylic resins. J Prosthodont. 2006 July-Aug;15(4):235-42. http://dx.doi.org/10.1111/j.1532-849X.2006.00112.x. PMid:16827736

9. Al-Huraishi H, Moran J, Jagger R, MacDonald E. Evaluation of stain removal and inhibition properties of eight denture cleansers: an in vitro study. Gerodontology. 2013 Mar;30(1):10-7. http://dx.doi.org/10.1111/j.1741-2358.2011.00522.x. PMid:23088443

10. Pavarina AC, Vergani CE, Machado AL, Giampaolo ET, Teraoka MT. The effect of disinfectant solutions on the hardness of acrylic resin denture teeth. J Oral Rehabil. 2003 July;30(7):749-52. http://dx.doi.org/10.1046/j.1365-2842.2003.01145.x. PMid:12791163

11. Machado AL, Breeding LC, Vergani CE, da Cruz Perez LE. Hardness and surface roughness of reline and denture base acrylic resins after repeated disinfection procedures. J Prosthet Dent. 2009 Aug;102(2):115-22. http://dx.doi.org/10.1016/S0022-3913(09)60120-7. PMid:19643225

12. Asad T, Watkinson AC, Huggett R. The effects of various disinfectant solutions on the surface hardness of an acrylic resin denture base material. Int J Prosthodont. 1993 Jan-Feb;6(1):9-12. PMid:8507335.

13. Neppelenbroek KH, Pavarina AC, Vergani CE, Giampaolo ET. Hardness of heat-polymerized acrylic resins after disinfection and long-term water immersion. J Prosthet Dent. 2005 Feb;93(2):171-6. http://dx.doi.org/10.1016/j.prosdent.2004.10.020. PMid:15674229

14. Ural C, Sanal FA, Cengiz S. Effect of different denture cleansers on surface roughness of denture base materials. Clin Dent Res. 2011; 5(2):14-20.

15. Žilinskas J, Junevičius J, Česaitis K, Junevičiūtė G. The effect of cleaning substances on the surface of denture base material. Med Sci Monit. 2013;19:1142-5. http://dx.doi.org/10.12659/MSM.889568. PMid:24326781

16. Jin C, Nikawa H, Makihira S, Hamada T, Furukawa M, Murata H. Changes in surface roughness and colour stability of soft denture lining materials caused by denture cleansers. J Oral Rehabil. 2003 Feb;30(2):125-30. http://dx.doi.org/10.1046/j.1365-2842.2003.01014.x. PMid:12535137

17. Regis RR, Soriani NC, Azevedo AM, Silva-Lovato CH, Paranhos HF, Souza RF. Effects of ethanol on the surface and bulk properties of a microwave-processed PMMA denture base resin. J Prosthodont. 2009 Aug;18(6):489-95.; June 3, 2009. http://dx.doi.org/10.1111/j.1532849X.2009.00475.x. PMid:19500235

18. Williams DW, Lewis MA. Isolation and identification of Candida from the oral cavity. Oral Dis. 2000 Jan;6(1):3-11. http://dx.doi. org/10.1111/j.1601-0825.2000.tb00314.x. PMid:10673781

\section{CONFLICTS OF INTERESTS}

The authors declare no conflicts of interest.

\section{${ }^{*}$ CORRESPONDING AUTHOR}

Fernanda Alves Feitosa, Departmento de Odontologia Restauradora, Instituto de Ciência e Tecnologia, UNESP - Univ Estadual Paulista, Avenida Engenheiro Francisco José Longo, 777, Jardim São Dimas, 12245-000 São José dos Campos - SP, Brazil, e-mail: fernanda.feitosa@fosjc.unesp.br 